\title{
Counterproductive Work Behavior and Organizational Citizenship Behavior Barbara Sypniewska
}

University of Economics and Human Sciences in Warsaw

Counterproductive work behavior (CWB) and organizational citizenship behavior (OCB) are two seemingly opposite types of active and volitional behaviors. However, previous research on the mutual relationships between these two types of behavior has yielded inconclusive results. Such relationships are of particular interest in countries such as Poland, which is still in the process of economic and social transformation from a communist to a capitalist system. Therefore, the current study sought to re-examine the relationships between OCB and CWB in a large sample of Polish employees. One thousand and fifty-one employees were recruited from small, medium, and large Polish enterprises to take part in the study, and they completed questionnaire measures of CWB and OCB. The results showed that the overall frequencies of CWB and OCB were statistically significantly correlated. However, while some dimensions of OCB were found to be significantly negatively correlated with certain categories of CWB, one dimension of $O C B$ was significantly positively correlated with CWB. Cluster analysis allowed for distinguishing of four subgroups of participants with different profiles of $C W B$ and $O C B$, including a subgroup that exhibited equal levels of $O C B$ and CWB and a subgroup that exhibited high levels of CWB cooccurring with increased frequencies of some dimensions of OCB. These results demonstrate that, overall, CWB and OCB are relatively independent and unrelated constructs; however, their particular dimensions may show a more complex pattern of relationships.

\author{
KEYWORDS \\ counterproductive work \\ behavior \\ organizational citizenship \\ behavior
}

\section{INTRODUCTION}

Counterproductive work behavior (CWB) and organizational citizenship behavior (OCB) are two types of active and volitional behavior that are often studied by researchers of organizational behavior. CWB, which might harm the organization, and OCB, which is beneficial, are often studied separately and are usually treated as opposites with respect to their determinants and consequences (Dineen et al., 2006). Some studies on the relationships between positive and negative citizenship behavior, including CWB, have been published in recent years (Glińska-Neweś \& Lis, 2016); however, their results remain inconclusive.

\section{Organizational Citizenship Behavior}

The concept of OCB was defined by Organ (1988) as "individual behavior that is discretionary, not directly or explicitly recognized by the formal reward system and that in the aggregate promotes the effective functioning of the organization" (p. 4). In his research on OCB, Organ underscored the motivational aspect. He assumed the voluntary nature of behaviors unrelated to the formal requirements of an employee's position and the lack of relationship to the reward system (Organ et al., 2006).

Constructs similar to OCB, as defined by Organ, can be found in the literature, including prosocial organizational behavior (Podsakoff et al., 2000), contextual performance (Borman \& Motowidlo, 1993, p. 71-98), organizational spontaneity (Brief \& Weiss, 2002), or extrarole behavior (Van Dyne et al., 1995).

The most popular model describes seven dimensions of OCB (Glińska-Neweś \& Lis, 2016, p. 140-142, qtd in. Organ et al., 2006; Podsakoff et al., 2000):

Corresponding author: Barbara Sypniewska, University of Economics and Human Sciences in Warsaw, Okopowa 59, 01-043 Warsaw, Poland.

E-mail: agata.sypni@op.pl 
1. Altruism/helping behavior - voluntarily offering support to coworkers to alleviate or prevent problems.

2. Organizational compliance - internalization and acceptance of organizational rules and norms, following them even when not monitored.

3. Sportsmanship - readiness to tolerate difficulties and discomfort. 4. Organizational loyalty - readiness to preserve and promote the organization's image.

5. Individual initiative - going above one's responsibilities.

6. Civic virtue - readiness to become responsibly engaged in the organization's life.

7. Self-development - voluntary behaviors aimed at increasing one's knowledge and skills.

Some researchers have proposed two more constructs as belonging to OCB (Glińska-Neweś, 2017, p. 140-142):

8. Courtesy - behaviors aimed at avoiding making problems for coworkers. Courtesy and altruism together form the dimension of helping behavior.

9. Conscientiousness - behaviors reflecting allegiance to the organization, namely, going above the minimal requirements of one's position. When analyzing OCB, attention must be given to its determinants. Aside from contextual factors (Podsakoff et al., 2000) that are directly shaped by the organization, the literature also points to personality traits that remain outside of the organization's control (Keplinger et al., 2014; Organ, 1988; Retowski \& Kaźmierczak, 2008; Turek, 2014).

\section{Counterproductive Work Behavior}

Counterproductive work behavior is often contrasted with OCB, which belongs to the positive trend of organizational research (Glińska-Neweś \& Lis, 2016). Conceptually, CWB is most often used interchangeably with terms such as workplace deviance behavior, which is used in sociological research (Robinson \& Bennett, 1995); the term counterproductive work behavior (CWB) stems from workplace and organizational psychology (Sackett, 2002). Counterproductive work behavior is considered to comprise voluntary activities that harm organizations, clients, coworkers, and supervisors (Spector \& Fox, 2005). In this view, the chief feature of CWB is its voluntary character; it results from an employee's decision (conscious or not) to undertake activities that are harmful for the organization or its members. From the employee's perspective, CWB is most often excused.

Researchers of CWB often consider it to be related to aggression (Douglas \& Martinko, 2001), workplace deviance (Robinson \& Bennett, 1995), revenge (Bies et al., 1997; Skarlicki \& Folger, 1997), or protest (Kelloway et al., 2010). For example, revenge and protest can be responses to injustice. On the other hand, aggression is tied to negative emotions such as anger and frustration, which can be responses to workplace conditions or a sense of injustice in the workplace. Counterproductive work behavior might result in financial, personal, and organizational costs (DeShong et al., 2015). Similar to OCB, research on CWB focuses on personality determinants (Bowling \& Eschleman, 2010; O’Boyle et al., 2012) and the organization's environmental factors (Ones \& Dilchert, 2013). Other researchers have sug- gested that these two sets of factors interact (Folger \& Skarlicki, 1998; Penney et al., 2011).

One of the most popular models of CWB is the one proposed by Spector, Fox, Penney, Bruursema, Goh, and Kessler (2006). It consists of the following five dimensions:

1. Abuse against others - physical and psychological aggression directed against coworkers, for example, threats, disparaging comments, ignoring others.

2. Production deviance - purposeful deviation from or neglect of the standard in fulfilling one's responsibilities.

3. Sabotage - purposefully destroying or damaging the organization's property.

4. Theft - stealing the organization's and/or coworkers' property, together with a potential aggressive reaction intended to harm the organization.

5. Withdrawal - limiting time spent at work to levels below the required norm, for example, through unexcused absences, leaving work early, taking breaks above the allowed time limit, or late arrivals.

This model has been empirically verified in numerous studies. These studies have used most of the aforementioned variables but have eliminated the "sensitive" or specific (not suitable for every workplace) ones (Glińska-Neweś, 2017, p. 149-150).

\section{The Relationships Between Organizational Citizenship Behavior and Counterproductive Work Behavior}

Although OCB and CWB seem to be opposite in nature, some studies have suggested that the relationships between these two categories of behavior might be more complex than initially assumed.

In the 1930s, OCB was defined as voluntary actions undertaken by employees for the common good. However, more recent accounts conceptualize OCB as a complex and multidimensional psychosocial phenomenon (Barabasz \& Chwalibóg, 2013). Individuals engaging in prosocial behaviors might simultaneously engage in unethical workplace behaviors, including CWB (Dalal, 2005). As Turek (2016) pointed out, many terms have been introduced to reflect the paradox of unethical organizational citizens. According to Turek, this implies a more complex perspective of $\mathrm{OCB}$, which requires considering the entirety of the organization through the lens of its social context.

Other authors have claimed that CWB might represent so-called constructive deviations, that is, behaviors that violate organizational and social norms but have beneficial consequences for the organization's effectiveness (Turek, 2015, s. 151-174).

Dalal (2005) stated that the links between OCB and CWB are related to social exchange theory, the psychological contract, and the social norm of reciprocity, as well as personality traits and organizational factors. Thus, different groups of factors determine employee behaviors. It is difficult to unambiguously locate the determinants of positive or negative relationships between OCB and CWB. Individuals might exhibit different manifestations of their personality traits depending on the situation. These manifestations might also be responses to signals from the workplace environment (Tett \& Burnett, 2003). Dalal (2005) 
pointed out that the relationship between OCB and CWB might be moderated by the source of evaluation, that is, evaluations formed by the supervisor of the employee (self-esteem) based on their impressions. The supervisor might assign high OCB/low CWB ratings to an employee who makes a positive impression and low $\mathrm{OCB} /$ high $\mathrm{CWB}$ ratings to an employee who makes a negative impression. Moreover, employees engage in OCB and/or CWB based on their goals. Thus, an employee might frequently help but also frequently harm others. Alternatively, an employee might rarely help and rarely harm others, frequently help and rarely harm others, or rarely help and frequently harm others. This is because employees can ascribe different goals to these behaviors. Dalal (2005) pointed out that some authors have claimed the purpose of OCB and/or CWB to be emotion regulation, i.e., bringing about a good mood or a sense of satisfaction. Individuals often engage in subtle behaviors to improve their affective states (Spector \& Fox, 2002). According to Dalal (2005), a direct relationship between OCB and CWB cannot be assumed, as there exist various categories of $\mathrm{OCB}$ and $\mathrm{CWB}$, together with various reasons for engaging in these behaviors. Additionally, the OCB-CWB relationship might be moderated by a range of other variables.

To expand the knowledge on the relationship between OCB and CWB, the current study examined whether CWB levels decrease as the levels of individual OCB dimensions increase. Additionally, total and individual dimension $\mathrm{OCB}$ and $\mathrm{CWB}$ scores were measured in the entire sample as well as in the distinguished subgroups. The results thus contribute to the existing knowledge about the relationship between $\mathrm{OCB}$ and $\mathrm{CWB}$.

\section{METHODS}

\section{Materials}

Counterproductive work behavior was measured using the Counterproductive Work Behavior Checklist (CWB-C) by Spector et al. (2006). This checklist consists of 32 items. Responses are given on a 5-point scale (never, 1-2 times, 1-2 times per week, 1-2 times per month, every day). This is a shortened version of the measure recommended by Spector et al. The 32 items are divided into five categories: abuse against others, production deviance, sabotage, theft, and withdrawal. A strength of the CWB-C is that its subscales are clearly defined and can be treated as separate. Specific behaviors are classified into one category and do not appear in others. The CWB-C is available in many languages, including English, German, and Spanish (Szostek, 2019, p. 82-83).

Organizational citizenship behavior was measured with the Organizational Citizenship Behavior Checklist (OCB-C). This checklist consists of 24 items comprising five dimensions: altruism, courtesy, conscientiousness, sportsmanship, and civic virtue (Podsakoff et al., 1990). The sum of the individual dimension scores forms the total OCB score (Fox et al., 2012). The respondents estimate how often they engage in each OCB on a five-point scale (never, 1-2 times, 1-2 times per week, 1-2 times per month, every day). The OCB-C items do not overlap with the CWB-C items in meaning (Dalal, 2005; Spector \& Fox, 2010).

\section{Participants and Procedure}

The study was carried out on a sample of employees of small, medium, and large enterprises. Participation in the study was voluntary and anonymous. Overall, 1051 employees participated in the study. Employment in an enterprise in Poland, regardless of its size, was the selection criterion. A short instruction explaining the purpose of the study was presented before the measures were distributed, and a series of sociodemographic questions were ultimately included. Women comprised $68 \%$ of the sample. The majority of the participants were 20-29 years old (65\%). The most frequent workplace position in the sample was that of a specialist (51\%); managerial and self-employment positions were the least frequent positions. The majority of the sample had been employed in their current workplace for 1 to 3 years (42\%). Employment of over 10 years in the current workplace was reported the least frequently. Most participants were employed in large enterprises of over 250 employees (43\%), most often on the basis of an indefinite employment contract. The majority of the enterprises were Polish (68\%). They were most often employed at limited liability companies (39\%).

\section{Statistical Analysis}

Descriptive statistics were calculated first. Then, a Pearson's $r$ correlation analysis was carried out for the individual dimensions of CWB and OCB. The correlation analysis was supplemented by a k-means cluster analysis including standardized values of the analyzed variables. Groups of participants characterized by different CWB and OCB profiles were distinguished. Descriptive statistics are shown in Table 1. Cronbach's $\alpha$ values for each CWB and OCB dimension were either optimal or high.

\section{RESULTS}

\section{Organizational Citizenship Behavior and Counterproductive Behavior}

Table 2 shows the Pearson's $r$ correlation coefficients for the dimensions of $\mathrm{OCB}$ and $\mathrm{CWB}$.

Weak but statistically significant negative correlations were revealed between the OCB dimensions of altruism, courtesy, and conscientiousness and all CWB dimensions. A stronger, positive correlation also emerged between the OCB dimension of sportsmanship and all CWB dimensions.

There were no statistically significant correlations between CWB and the OCB dimension of civic virtue. Total CWB was negatively correlated with the OCB dimensions of altruism, courtesy, and conscientiousness and was positively correlated with sportsmanship. Total OCB was negatively correlated with withdrawal. 


\begin{tabular}{|c|c|c|c|c|c|}
\hline $\begin{array}{l}\text { Counterproductive } \\
\text { work behavior }\end{array}$ & $M$ & $S D$ & $\min$ & $\max$ & Cronbach's $\alpha$ \\
\hline Theft & 6.42 & 2.96 & 4 & 21 & 0.87 \\
\hline Abuse against others & 21.72 & 9.50 & 14 & 73 & 0.96 \\
\hline Sabotage & 3.71 & 1.73 & 1 & 15 & 0.80 \\
\hline Production deviance & 7.24 & 3.10 & 3 & 20 & 0.78 \\
\hline Withdrawal & 4.14 & 1.99 & 1 & 15 & 0.81 \\
\hline $\begin{array}{l}\text { Organizational } \\
\text { citizenship behavior }\end{array}$ & $M$ & $S D$ & $\min$ & $\max$ & Cronbach's $\alpha$ \\
\hline Altruism & 18,18 & 5.02 & 4 & 25 & 0.91 \\
\hline Courtesy & 17,55 & 5.34 & 2 & 25 & 0.85 \\
\hline Conscientiousness & 17,16 & 4.64 & 1 & 25 & 0.68 \\
\hline Sportsmanship & 11,10 & 5.08 & 2 & 25 & 0.88 \\
\hline Civic virtue & 12,34 & 4.47 & 1 & 20 & 0.84 \\
\hline
\end{tabular}

\section{Cluster Analysis}

The correlation analysis was supplemented by a k-means cluster analysis including the standardized values of the CWB and OCB scores. The final centers of the identified clusters are shown in Figure 1, with the scores transformed into standardized $z$ scores. The value of 0 denotes the mean level of the variable in the sample. Positive values denote the number of $S D$ s above this mean, and negative values denote the number of SDs below it. The mean values of CWB and OCB for each identified cluster are shown in Table 3, along with the results of analysis of variance (ANOVA).

Statistically significant differences between most of the clusters were confirmed using the Gabriel post hoc test. However, Clusters 1 and 3 did not differ with respect to scores on the CWB dimensions of theft, abuse against others, and sabotage. Clusters 1 and 2 did not differ with respect to results on the OCB dimensions of altruism and sportsmanship. Clusters 2 and 3 did not differ with respect to results on the OCB dimension of conscientiousness. Finally, Clusters 1 and 4 did not differ with respect to results on the OCB dimension of civic virtue.

The first, most numerous cluster $(n=544)$ comprised individuals characterized by average CWB and OCB levels.

The second cluster $(n=123)$ comprised individuals who achieved higher scores on the CWB dimension of withdrawal together with average OCB levels.
The third cluster $(n=298)$ comprised individuals whose CWB and OCB levels were average but lower than those in Cluster 1.

The fourth cluster $(n=77)$ comprised individuals characterized by very high CWB levels, above-average scores on the OCB dimension of sportsmanship, and average scores on the remaining OCB dimensions.

\section{DISCUSSION}

The results of the current study show that as altruism, courtesy, and conscientiousness scores increase, the strength of the relationship with all CWB dimensions decreases. Some research points to the fact that altruistic behaviors can target employees who exhibit lower levels of performance, for example, due to absences or lack of skills. Coworkers offer help in these instances. However, when an employee purposefully lowers their performance level, they can become targets of CWB (Perrewe \& Zellars, 1999). Social perception plays an important role in CWB targeted at organization members (Liden et al., 2004).

Altruism and courtesy refer to helping coworkers. Conscientiousness involves going above the minimal requirements of one's positions, for example, regarding adherence to norms, organizational procedures and break durations (Glińska-Neweś, 2017, p. 148154). The results of the current study show that the differences between these dimensions are large and lead to different relationships between individual CWB dimensions; the stronger the OCB dimensions of altruism and courtesy are, that is, helping coworkers and achieving performance levels above the required organizational norm, the more frequently employees engage in CWB.

However, this is not always the case. Further analysis of the obtained results and the distinguished clusters identified individuals who exhibited OCB through increased sportsmanship while simultaneously engaging more frequently in CWB. It might be the case that an employee who is engaged in their duties and who displays persistence in goal achievement expects recognition from his or her supervisor or the organization. When this recognition is lacking, negative emotions may arise, especially anger, dissatisfaction, and a sense of injustice. Research shows that CWB is related to a sense of injustice in the workplace and a stressful workplace environment (Fox et al., 2001). Dalal (2005) also showed that OCB emerges in the context of job satisfaction and perceiving the workplace as fair. Satisfied employees are more likely to engage in OCB and less likely to engage in CWB. As

\section{TABLE 2}

Correlations Between Organizational Citizenship Behavior and Counterproductive Work Behavior Dimensions

\begin{tabular}{lcccccc}
\hline \multirow{2}{*}{$\begin{array}{c}\text { Counterproductive } \\
\text { work behavior }\end{array}$} & \multicolumn{5}{c}{ Organizational citizenship behavior } \\
\cline { 2 - 7 } & Altruism & Courtesy & Conscientiousness & Sportsmanship & Civic virtue & Total \\
\hline Theft & $-.138^{* *}$ & $-.097^{* *}$ & $-.078^{*}$ & $.284^{* *}$ & .049 & .007 \\
Abuse against others & $-.135^{* *}$ & $-.137^{* *}$ & $-.087^{* *}$ & $.339^{* *}$ & .058 & .009 \\
Sabotage & $-.159^{* *}$ & $-.104^{* *}$ & $-.109^{* *}$ & $.229^{* *}$ & .006 & -.039 \\
Production deviance & $-.129^{* *}$ & $-.121^{* *}$ & $-.190^{* *}$ & $.205^{* *}$ & -.035 & $-.082^{* *}$ \\
Withdrawal & $-.158^{* *}$ & $-.145^{* *}$ & $-.140^{* *}$ & $.294^{* *}$ & .001 & -.043 \\
Total & $-.158^{* *}$ & $-.143^{* *}$ & $-.121^{* *}$ & $.330^{* *}$ & .035 & -.016 \\
\hline
\end{tabular}

$$
{ }^{\star} p<.05 ;{ }^{* *} p<.01
$$




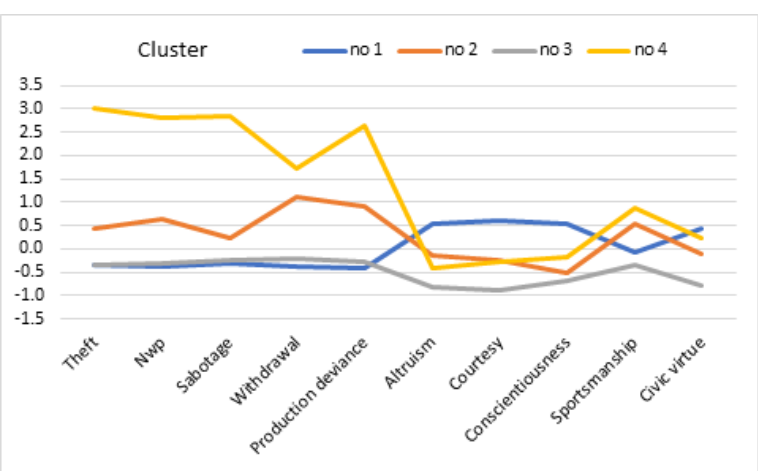

FIGURE 1.

Mean values of standardized results on the counterproductive work behavior and organizational citizenship behavior subscales in the distinguished clusters.

one of the motives of engaging in OCB and not engaging in OCB, a sense of injustice can lead to withdrawal from work. When they are not acknowledged by supervisors (e.g., by receiving thanks), OCB can lead to anger and, finally, to CWB. The link between a sense of injustice and CWB has been confirmed in numerous studies (Skarlicki \& Folger, 1997). Engaging in CWB causes guilt, which in turn can motivate engagement in $\mathrm{OCB}$ to alleviate the guilt. In such cases, the combination of CWB and OCB can be considered from the perspective of the sense of justice and equality. Altruistic behaviors can be motivated by the desire to lower guilt, increase one's self-esteem, and repair one's self-image (Batson, 1990; Batson \& Shaw, 1991). Guilt leads to OCB to repair the previously caused damage and restore a sense of justice. Researchers criticizing this approach have pointed out that the sense of justice has been overemphasized, leading to other factors becoming neglected (Zellars \& Tepper, 2003, p. 395-424). Research on the role of stress (Miles et al., 2002), personality factors, and workplace environment (Liu \& Perrewe, 2005; Skuzińska et al., 2019) has also suggested. It must be noted that CWB harms the organization and/or its members through insulting and disparaging treatment of others, theft, and withdrawal from work (Spector et al., 2006).

The current study identified groups (clusters) of participants who were characterized by average CWB and OCB levels. Dalal (2005), sim- ilar to many other authors, showed that OCB and CWB do not form opposite poles. Thus, a lack of negative behaviors does not necessarily imply that only positive behaviors occur in the organization. Likewise, no positive behaviors do not mean that only negative behaviors occur (Dalal, 2005). Counterproductive work behavior and OCB are positively correlated at the employee and organizational levels, and they can occur simultaneously or sequentially (Sackett \& DeVore, 2002). Based on internal and external determinants, employees can engage in both behavior types. Thus, these behaviors can coexist or occur with average frequency (Klotz \& Bolino, 2013). The results of the current study showed that some individuals are also characterized by increased withdrawal while simultaneously exhibiting average OCB levels.

Studies on the determinants of OCB have showed that individuals engage in these behaviors to obtain an expected reward (Rioux \& Penner, 2001) or build their reputation, regardless of how well they perform at work (Yun et al., 2007).

\section{CONCLUSIONS}

There is no agreement among researchers on whether OCB is strongly correlated with CWB. Some studies have reported negative OCBCWB correlations (Lee \& Allen, 2002), while others have not yielded statistically significant results (Marcus et al., 2002) or showed strong negative (Sackett, 2002) or positive (Dalal et al., 2009) correlations. A problematic aspect of many studies on OCB and CWB concerns their motivating factors. It is unclear whether the motivations behind these behaviors are related to their effects. An employee engaging in CWB might report their improper behavior to the supervisor to justify it. This can be understood as rationalization (Kosewski, 2008) to alleviate guilt. On the other hand, employees engaging in CWB might be treated badly by their supervisors, in contrast to employees engaging in OCB. Thus, further research, which would consider OCB and CWB not only as separate but also interrelated, is required. Future studies should also take into account the temporal dimension in relation to the determinants and effects of OCB and CWB. Moreover, both quantitative and qualitative studies should be carried out. Qualitative studies should examine the motivations behind both incidental behaviors and more

TABLE 3.

Final Cluster Centers and Significance of Differences Test Results

\begin{tabular}{lccccccccccc}
\hline & \multicolumn{1}{c}{ Cluster } \\
\cline { 2 - 13 } & \multicolumn{1}{c}{1} & \multicolumn{1}{c}{2} & \multicolumn{1}{c}{3} & & 4 & & & \\
\cline { 2 - 13 } & $M$ & $S D$ & $M$ & $S D$ & $M$ & $S D$ & $M$ & $S D$ & $F$ & $p$ \\
\hline Theft & -0.34 & 0.28 & 0.44 & 0.80 & -0.33 & 0.31 & 3.01 & 1.00 & 1256.38 & .001 \\
Abuse against others & -0.37 & 0.32 & 0.62 & 0.83 & -0.31 & 0.43 & 2.82 & 1.04 & 951.85 & .001 \\
Sabotage & -0.32 & 0.29 & 0.24 & 0.81 & -0.24 & 0.42 & 2.85 & 1.43 & 726.58 & .001 \\
Withdrawal & -0.39 & 0.64 & 1.12 & 0.89 & -0.21 & 0.76 & 1.74 & 0.94 & 296.97 & .001 \\
Production deviance & -0.42 & 0.34 & 0.91 & 0.84 & -0.29 & 0.46 & 2.63 & 1.01 & 905.49 & .001 \\
Altruism & 0.54 & 0.72 & -0.16 & 0.76 & -0.82 & 0.95 & -0.42 & 0.79 & 195.49 & .001 \\
Courtesy & 0.59 & 0.64 & -0.24 & 0.82 & -0.89 & 0.91 & -0.29 & 0.74 & 256.05 & .001 \\
Conscientiousness & 0.53 & 0.76 & -0.51 & 0.74 & -0.70 & 0.94 & -0.17 & 0.91 & 162.30 & .001 \\
Sportsmanship & -0.06 & 1.03 & 0.54 & 0.92 & -0.36 & 0.77 & 0.89 & 0.84 & 52.46 & .001 \\
\hline
\end{tabular}

Note. $d f=3.1038$ 
long-term processes. Organizations might encourage their employees to engage in OCB, but it must be noted that employees might interpret this encouragement as being unwarranted or demanding. This might result in contrary behaviors, thereby making employees more likely to engage in CWB in conjunction with OCB. The literature indicates different research results in regard to the relationship between civic and counterproductive behaviors. Perhaps such outcomes depend on the choice of research sample or research area. Such a situation prompts us to more precisely examine these relationships in Poland.

The results of the current study contribute to the research on the assumption that OCB and CWB are usually undertaken by different employees in different organizations. The latest research on OCB and CWB suggests that these behaviors are complex processes that cannot be treated as simple behavioral schemas. It is recommended that future research use mediation or moderation to investigate the relationship between civic and counterproductive behaviors.

\section{REFERENCES}

Barabasz, A., \& Chwalibóg, E. (2013). Refleksje nad konsekwencjami zachowań obywatelskich w organizacjach [Reflections on the consequences of citizenship behaviors in organizations]. Acta Universitatis Lodziensis. Folia Oeconomica, 282, 23-32.

Batson, C. D. (1990). Affect and altruism. Cambridge University Press; Editions de la Maison des Sciences de l'Homme.

Batson, C. D., \& Shaw, L. L. (1991). Evidence for altruism: Toward a pluralism of prosocial motives. Psychological Inquiry, 2, 107-122. doi: 10.1207/s15327965pli0202_1 المالسلس

Bies, R. J., Tripp, T. M., \& Kramer, R. M. (1997). At the breaking point: Cognitive and social dynamics of revenge in organizations. In R. A. Giacalone \& J. Greenberg (Eds.), Antisocial behavior in organizations (pp. 18-36). Sage.

Borman, W., \& Motowidlo, S. (1993). Expanding the criterion domain to include elements of contextual performance. In N. Schmitt \& W. Borman (Eds.), Personnel selection in organizations (pp. 71-98). Jossey-Bass.

Bowling, N. A., \& Eschleman, K. J. (2010). Employee personality as a moderator of the relationships between work stressors and counterproductive work behavior. Journal of Occupational Health Psychology 12, 91-103. doi: 10.1037/a0017326 سلسلسلس

Brief, A., \& Weiss, H. (2002). Organizational behavior: Affect in the workplace. Annual Review of Psychology, 53, 279-307. doi: 10.1146/ annurev.psych.53.100901.135156 الس الس

Dalal, R. (2005). A meta-analysis of the relationship between organizational citizenship behavior and counterproductive work behavior. Journal of Applied Psychology, 90, 1241-1255. doi: 10.1037/0021-

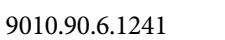

Dalal, R. S., Lam, H., Weiss, H. M., Welch, E. R., \& Hulin, C. L. (2009). A withinperson approach to work behavior and performance: Concurrent and lagged citizenship-counterproductivity associations, and dynamic relationships with affect and overall job performance. Academy of Management Journal, 52, 1051-1066. doi: 10.5465/amj.2009.44636148
DeShong, H., Grant, D., \& Mullins-Sweatt, S. (2015). Comparing models of counterproductive workplace behaviors: The Five-Factor Model and the Dark Triad. Personality and Individual Differences,

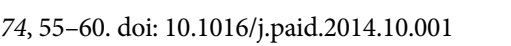

Dineen, B. R., Lewicki, R. J., \& Tomlinson, E. C. (2006). Supervisory guidance and behavioral integrity: Relationships with employee citizenship and deviant behavior. Journal of Applied Psychology, 91, 622-635. doi: 10.1037/0021-9010.91.3.622 المالسلبل

Douglas, S. C., \& Martinko, M. J. (2001). Exploring the role of individual differences in the prediction of workplace aggression. Journal of

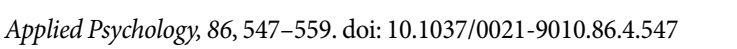

Folger, R. \& Skarlicki, D. P. (1998). A popcorn metaphor for employee aggression. In R. W. Griffin, A. O’Leary-Kelly, \& J. M. Collins (Eds.), Dysfunctional behavior in organizations: Violent and deviant behavior (pp. 43-81). JAI Press;

Fox, S., Spector, P.E., \& Miles, D. (2001). Counterproductive work behavior $(\mathrm{CWB})$ in response to job stressors and organizational justice: Some mediator and moderator tests for autonomy and emotions. Journal of Vocational Behavior, 59, 291-309. doi: 10.1006/ jvbe.2001.1803 الس سلس

Fox, S., Spector, P., Goh, A., Bruursema, K., \& Kessler, S. (2012). The deviant citizen: Measuring potential positive relations between counterproductive work behaviour and organizational citizenship behaviour. Journal of Occupational and Organizational Psychology, 85, 199-220. doi: 10.1111/j.2044-8325.2011.02032.x المالسلسلس

Glińska-Neweś A., (2017). Pozytywne relacje interpersonalne $w$ zarzadzaniu [Positive interpersonal relationships in management]. Wydawnictwo Naukowe Uniwersytetu Mikołaja Kopernika.

Glińska-Neweś, A., \& Lis, A. (2016). Paradoks współwystępowania organizacyjnych zachowań obywatelskich i kontrproduktywnych [The paradox of the co-occurence of organizational citizenship behaviors and counterproductive work behaviors]. Prace Naukowe Uniwersytetu Ekonomicznego we Wrocławiu, 422, 265-274. المالسلسلاس

Kelloway, E., Francis, L., Prosser, M., \& Cameron, J. (2010). Counterproductive work behavior as protest. Human Resource Management Review, 20, 18-25. doi: 10.1016/j.hrmr.2009.03.014 الملسلسلس Keplinger, A., Frątczak, E. Ławecka, K., \& Stokłosa, P, (2014). Zachowania etosowe $\mathrm{w}$ kontekście pracy zawodowej [Ethical behavior in the workplace context]. Prace Naukowe Uniwersytetu

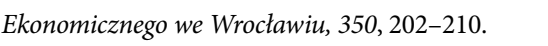

Klotz A. C., \& Bolino M. C. (2013), Citizenship and counterproductive work behavior: A moral licensing view. Academy of Management Review, 38, 292-306. doi: 10.5465/amr.2011.0109 السلسلسل

Kosewski, M. (2008). Wartość, godność i władza [Values, dignity, and power]. Vizja.

Lee, K., \& Allen, N. J. (2002). Organizational citizenship behavior and workplace deviance: The role of affect and cognitions. Journal of Applied Psychology, 87, 131-142. doi: 10.1037/0021-9010.87.1.131 المالسلس

Liden, R. C.,Wayne, S. J., Jaworski, R. A., \& Bennett, N. (2004). Social loafing: A field investigation. Journal of Management, 30, 285-304. doi: 10.1016/j.jm.2003.02.002 الس الس

Liu, Y., \& Perrewé, P. L. (2005). The role of emotion in employee coun- 
terproductive work behavior: Integrating the psychoevolutionary and constructivist perspective. Lawrence Erlbaum Associates.

Marcus, B., Schuler, H., Quell, P., \& Humpfer, G. (2002). Measuring counterproductivity: Development and initial validation of a German self-report questionnaire. International Journal of Selection and Assessment, 10, 18-35. doi: 10.1111/1468-2389.00191 السلسلس

Miles, D. E., Borman, W. E., Spector, P. E., \& Fox, S. (2002). Building an integrative model of extra role work behaviors: A comparison of counterproductive work behavior with organizational citizenship behavior. International Journal of Selection and Assessment, 10, 51-57. doi: 10.1111/1468-2389.00193

O’Boyle, E. H., Forsyth, D. R., Banks, G. C. \& McDaniel, M. A. (2012). A meta-analysis of the Dark Triad and work behavior. A social exchange perspective. Journal of Applied Psychology, 97, 557-579. doi: 10.1037/a0025679 سلس

Ones, D. \& Dilchert, S. (2013). Counterproductive work behaviors: Concepts, measurement, and nomological network. In K. Geisinger, B. Bracken, J. Carlson, J. Hansen, N. Kuncel, S. Reise, \& M. Rodriguez (Eds.), APA handbook of testing and assessment in psychology (pp. 643-659). American Psychological Association.

Organ, D. (1988). Organizational citizenship behavior: The good soldier syndrome. Lexington Books.

Organ, D., Podsakoff, P., \& MacKenzie, S. (2006). Organizational citizenship behavior: Its nature, antecedents, and consequences. Sage Publications.

Penney, L. M., Hunter, E. M., \& Perry, S. J. (2011). Personality and counterproductive work behavior. Using conservation of resources theory to narrow the profile of deviant employees. Journal of Occupational and Organizational Psychology, 84, 58-77. doi: 10.1111/j.2044-8325.2010.02007.x الم

Perrewé, P. L., \& Zellars, K. L. (1999). An examination of attributions and emotions in the transactional approach to the organizational stress process. Journal of Organizational Behavior, 20, 739-752. doi: 10.1002/(SICI)1099-1379(199909)20:5<739::AIDJOB1949>3.0.CO;2-C Tلسلس

Podsakoff, P. M., MacKenzie, S. B., Moorman, R. H., \& Fetter, R. (1990). Transformational leader behaviors and their effects on followers' trust in leader, satisfaction, and organizational citizenship behaviors. Leadership Quarterly, 1, 107-142. doi: 10.1016/1048-

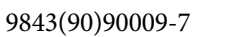

Podsakoff, P., MacKenzie, S., Paine, J., \& Bachrach, D. (2000). Organizational citizenship behaviors: A critical review of the theoretical and empirical literature and suggestions for future research. Journal of Management, 26, 513-563. doi: 10.1016/S01492063(00)00047-7 س山

Retowski, S., \& Kaźmierczak, M. (2008). Osobowościowe predyktory zachowań etosowych $\mathrm{w}$ organizacji [Personality predictors of ethical behaviors in the organization]. Roczniki Psychologiczne, 2, 87-105. 1لسلسلس

Rioux, S. M., \& Penner, L. A. (2001). The causes of organizational citizenship behavior: A motivational analysis. Journal of Applied Psychology, 86, 1306-1314. doi: 10.1037/0021-9010.86.6.1306 المالسلكسا Robinson, S. L., \& Bennett, R. J. (1995). A typology of deviant work- place behaviors: A multidimensional scaling study. Academy of Management Journal, 38, 555-572. doi: 10.5465/256693 المالسلس

Sackett, P. (2002). The structure of counterproductive work behaviors: Dimensionality and relationships with facets of job performance. International Journal of Selection and Assessment, 10, 5-11. doi: 10.1111/1468-2389.00189 (10)

Sackett, P. R., \& DeVore, C. J. (2002). Counterproductive behaviors at work. Sage.

Skarlicki, D. P., \& Folger, R. (1997). Retaliation in the workplace: The roles of distributive, procedural, and interactional justice. Journal of Applied Psychology, 82, 434-443. doi: 10.1037/0021-9010.82.3.434 الهالسلسليا

Skuzińska A., Plopa M., \& Plopa W. (2019). Bullying at work and mental health: The moderating role of demographic and occupational variables. Advances in Cognitive Psychology, 16, 13-23. doi: 10.5709/ acp-0280-9 المالسلس

Spector, P. E., \& Fox, S. (2002). An emotion-centered model of voluntary work behavior: Some parallels between counterproductive work behawior and organizational citizenship behavior. Human Resource Management Review, 12, 269-292. doi: 10.1016/S10534822(02)00049-9 سلسلس

Spector, P. E., \& Fox, S. (2005). A model of counterproductive work behavior. In S. Fox \& P. E. Spector (Eds.), Counterproductive workplace behavior: Investigations of actors and targets (pp. 151-174). APA.

Spector, P., \& Fox, S. (2010). Counterproductive work behavior and organisational citizenship behavior: Are they opposite forms of active behavior? Applied Psychology, 59, 21-39. doi: 10.1111/j.14640597.2009.00414.x سلس

Spector, P., Fox, S., Penney, L., Bruursema, K., Goh, A., \& Kessler, S. (2006). The dimensionality of counterproductivity: Are all counterproductive behaviors created equal? Journal of Vocational Behavior, 68, 446-460. doi: 10.1016/j.jvb.2005.10.005 السلسلسلة

Szostek, D. (2019). Kontrproduktywne zachowania organizacyjne $w$ kontekście jakości relacji interpersonalnych $w$ zespołach pracowniczych [Counterproductive work behaviors in the context of interpersonal relationship quality in workplace teams]. Wydawnictwo Naukowe Uniwersytetu Mikołaja Kopernika.

Tett, R. P., \& Burnett, D. D. (2003). A personality trait-based interactionist model of job performance. Journal of Applied Psychology, 88, 500-517. doi: 10.1037/0021-9010.88.3.500 1ل

Turek, D. (2014). Citizenship behaviors in the workplace: The relationships between psychological capital and Leader-Member Exchange. The mediating role of organizational justice and job satisfaction. Organizacja i Zarządzanie: Kwartalnik Naukowy, 4, 159-185. 友

Turek, D. (2015). Paradoksy „ciemnej strony” zachowań organizacyjnych. Kiedy i jak dewiacyjne zachowania wyzwalają pozytywne konsekwencje organizacyjne? [The paradoxes of the "dark side" of organizational behaviors. When and how deviant behaviors facilitate positive organizational consequences?] In L. Kiełtyka, W. Jędrzejczyk, \& P. Kobis (Eds.), Wyzwania współczesnego zarządzania. Tendencje $w$ zachowaniach organizacyjnych (pp. 151-174). Wydawnictwo TNOiK „Dom Organizatora”.

Turek, D. (2016). Paradoksy "obywatelskich zachowań" pracowników 
w organizacji [The paradoxes of „citizenship behaviors” in organizations]. Organizacja i Kierowanie, 2, 131-143. Wلس

Van Dyne, L., Cummings, L. \& Parks, J. (1995). Extra-role behaviors: In pursuit of construct and definitional clarity. In L. Cummings \& B. Staw (Eds.), Research in organizational behavior (Vol 17, pp. 215-285). JAI Press.

Yun, S., Takeuchi, R., \& Liu, W. (2007). Employee self-enhancement motives and job performance behaviors: Investigating the moderating effects of employee role ambiguity and managerial percep- tions of employee commitment. Journal of Applied Psychology, 92, 745-756. doi: 10.1037/0021-9010.92.3.745 المالسلسلا

Zellars, K. L., \& Tepper, B. J. (2003). Beyond social exchange: New directions for organizational citizenship behavior theory and research. In J. J. Martocchio \& G. R. Ferris (Eds.), Research in personnel and human resources management (Vol. 22, pp. 395-424). Elsevier.

RECEIVED 30.05.2020 | ACCEPTED 30.09.2020 